\title{
Kolestasis pada Sepsis Neonatorum di RSUP Sanglah, Denpasar
}

\author{
I Putu Gede Karyana, I GN Sanjaya Putra, Ni Putu Veny Kartika Yanti \\ Bagian/SMF Ilmu Kesehatan Anak Fakultas Kedokteran Universitas Udayana/RSUP Sanglah, Denpasar
}

Latar belakang. Kolestasis neonatal masih merupakan permasalahan dibidang ilmu kesehatan anak. Angka kejadian kolestasis intrahepatal yang disebabkan oleh sepsis sebesar 65,9\% dengan angka kematian pada neonatus $52,8 \%$.

Tujuan. Mengetahui prevalensi dan luaran, faktor berhubungan dengan kejadian kolestasis pada sepsis neonatorum.

Metode. Desain potong lintang analitik pada neonatus terbukti sepsis, pengambilan data rekam medik dari Januari 2008 sampai dengan September 2010.

Hasil. Prevalensi kolestasis 38,9\% dengan penyebab terbanyak bakteri Gram negatif yaitu Serratia Marcescens (19,2\%). Lama rawat $\geq 15$ hari kolestasis dengan RR 1,57 (IK 95\% 0,029-0,116), rerata lama puasa 8,8 hari $\pm 6,81), p=0,001$, rerata lama pemberian nutrisi parenteral 14,2 hari $(S D=8,26), p=0,001$ merupakan faktor yang signifikan untuk terjadi kolestasis. Kadar rerata CRP 97,51 (74,94), kadar IT ratio 0,07 (0,05), kadar trombosit $60.250(60,950)$ bermakna berhubungan dengan kolestasis. Mortalitas pada sepsis neonatorum dengan kolestasis $23,3 \%$.

Kesimpulan. Prevalensi kolestasis pada sepsis neonatorum di RSUP Sanglah Denpasar didapatkan 38,9\%. Faktor lama rawat $\geq 15$ hari, lama puasa serta pemberian nutrisi parenteral dan rerata kadar CRP, IT ratio, serta kadar trombosit bermakna untuk terjadi kolestasis, dan angka kematian sepsis neonatorum dengan kolestasis 9\%. Sari Pediatri 2012;14(4):211-7.

Kata kunci: prevalensi, sepsis neonatorum, kolestasis, faktor risiko

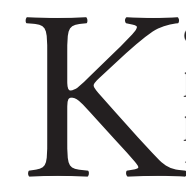

olestasis neonatal masih merupakan permasalahan dan deteksi dini sangat penting untuk mencari etiologi. Kolestasis merupakan suatu gejala dengan etiologi

\section{Alamat korespondensi:}

Dr. I Putu Gede Karyana, Sp.A. Bag/SMF Ilmu Kesehatan Anak Fakultas Kedokteran Universitas Udayana/RSUP Sanglah Denpasar. Jl. Pulau Nias Denpasar Bali. Telepon/Fax: (0361) 244038. E-mail: kyn_karyana@yahoo.co.id yang bermacam-macam dan salah satu penyebabnya, yakni infeksi virus, bakteri, dan parasit. ${ }^{1-6}$ Kolestasis pada neonatus terjadi pada $\pm 1: 2.500$ kelahiran hidup. ${ }^{6}$ Di Instalasi Rawat Inap Anak RSU Dr. Sutomo Surabaya antara tahun 1999-2004 terdapat 19.270 pasien rawat inap, di antaranya 96 pasien dengan neonatal kolestasis. Pada periode Januari sampai dengan Desember 2003 di Departemen Ilmu Kesehatan Anak FKUI/RSCM tercatat 99 pasien dengan kolestasis, 68 di antaranya dengan kolestasis 
intrahepatik. ${ }^{7}$ Prevalensi kolestasis yang disebabkan oleh sepsis berkisar 3\%-8\%. ${ }^{3}$ Penelitian Bachtiar ${ }^{8}$ di Jakarta, menemukan 65,9\% angka kejadian kolestasis pada sepsis neonatorum. Mortalitas sepsis neonatorum cukup tinggi berkisar 13\%-25\% dan angka mortalitas tersebut meningkat pada bayi kurang bulan dan bayi dengan sakit berat pada saat awal. Sepsis sendiri dapat menyebabkan kolestasis intrahepatik serta berperan dalam meningkatkan angka kematian 52,8\%. pada neonatus akibat kolestasis sepsis.

Sepsis sebagai penyebab kolestasis umumnya disebabkan oleh bakteri Gram negatif. ${ }^{7,9} 10$ Penelitian Bachtiar $^{8}$ menunjukkan berbagai faktor risiko seperti nilai laboratorium (leukosit, C-reactive protein/ CRP, imature total ratio/IT ratio) serta gejala klinis sepsis neonatorum tidak bermakna secara statiskik dengan kejadian kolestasis, sedangkan lama rawat $\geq 15$ hari 2,45 kali berisiko untuk terjadi kolestasis. Penelitian Wrigth $\mathrm{dkk}^{11}$ menunjukkan berat badan, durasi pemberian nutrisi parenteral, dan penggunaan nutrisi parenteral bermakna untuk terjadi kolestasis.

Dari latar belakang tersebut, maka deteksi dini terjadinya kolestasis pada sepsis neonatorum sangat penting. Penelitian kami bertujuan mengetahui prevalensi kolestasis, faktor risiko kolestasis, serta mengetahui luaran kolestasis pada sepsis neonatorum yang dirawat di ruang bayi RSUP Sanglah, Denpasar.

\section{Metode}

Penelitian potong lintang, dilaksanakan bulan Januari 2010 sampai dengan September 2010 di ruang rawat inap bangsal neonatologi dan neonatal intensive care unit (NICU) Bagian Ilmu Kesehatan Anak FK-UNUD/ RSUP Sanglah-Denpasar. Subyek penelitian adalah neonatus yang terbukti sepsis neonatorum dengan mengeksklusi data rekam medik yang tidak lengkap. Data dikumpulkan berupa nama, nomer rekam medis, jenis kelamin, berat badan lahir, umur kehamilan, hasil kultur darah, awitan sepsis, kuman penyebab sepsis, data kolestasis, kelainan bedah, lama puasa, pemberian nutrisi parenteral, nilai laboratorium seperti jumlah leukosit, trombosit, CRP, dan IT ratio.

\section{Definisi operasional variabel}

- Sepsis neonatorum adalah sindrom klinis yang ditandai dengan infeksi systemic inflammatory response syndrome/SIRS yang dipicu oleh infeksi berdasarkan kriteria klinis dan laboratoris disertai dengan bukti ditemukannya kuman penyebab dari hasil kultur darah.

- Kolestasis adalah jika didapatkan keadaan bilirubin direk $>1 \mathrm{mg} / \mathrm{dL}$ pada bilirubin total $<5 \mathrm{mg} / \mathrm{dL}$ atau bilirubin direk $>20 \%$ dari bilirubin total pada kadar bilirubin total $>5 \mathrm{mg} / \mathrm{dL}$.

- Usia kolestasis adalah usia pasien saat didiagnosis sebagai kolestasis

- Durasi nutrisi parenteral adalah lama pasien diberikan cairan yang terdiri dari minimal dekstrosa, asam amino dan atau lipid melalui intravena selama perawatan sebelum

- Lama rawat adalah waktu yang digunakan pasien untuk mendapat perawatan di ruang perawatan bayi yang dinilai dari tanggal keluar rumah sakit dikurangi tanggal masuk rumah sakit, dibagi menjadi $<15$ hari dan $\geq 15$ hari

- Luaran adalah keadaan bayi saat keluar rumah sakit setelah dirawat di ruang perawatan bayi, dibagi menjadi meninggal dan hidup

- Kadar leukosit, trombosit, IT ratio diambil dari data pemeriksaan darah lengkap saat didiagnosis kolestasis dengan pemeriksaan standar

- Kadar CRP diambil dari data laboratorium yang diperiksa bersamaan dengan evaluasi darah lengkap saat terdiagnosis kolestasis dengan pemeriksaan standar

Data dianalisis dengan menggunakan komputer dan dikomparasi dengan uji kui kuadrat atau uji Fisher atau uji Kolmogorov-Smirnov, uji student $\mathrm{T}$ berdasarkan jenis variabel serta uji multivariabel. Batas kemaknaan yang dipergunakan adalah alfa 5\% untuk interpretasi data.

\section{Hasil}

Data sampel diambil dari data rekam medik Januari 2008-September 2010. Terdapat 787 bayi dengan kecurigaan sepsis dan didapatkan 355 pasien dengan hasil kultur darah positif, 265 dengan kultur darah negatif serta 167 data tidak didapatkan di rekam medik. Data karakteristik sampel tertera pada Tabel 1.

Dari 355 pasien yang terbukti sepsis neonatorum, didapatkan 138 pasien $(38,9 \%)$ dengan kolestasis. Rerata awitan kolestasis 12,8 hari $(\mathrm{SB}=4,946)$ dan rerata 12 hari. Rerata kadar bilirubin total dan direk 
pada pasien kolestasis $13,2 \pm 9,4$ dan 7,9 9 .

Kami mendapatkan sebagian besar kasus terinfeksi bakteri Gram negatif yaitu 193 (54,4\%). Mikroorganisme tersering adalah Serratia marcescens 68 kasus (19,2\%). Jenis bakteri penyebab sepsis

Tabel 1. Karakteristik sepsis neonatorum $(\mathrm{n}=355)$

\begin{tabular}{lrr}
\hline Karakteristik & \multicolumn{2}{c}{ Jumlah $(\%)$} \\
\hline Jenis kelamin & & \\
Laki-laki & 209 & $(58,9)$ \\
$\quad$ Perempuan & 146 & $(41,1)$ \\
Keadaan saat lahir & & \\
$\quad$ Vigorous baby & 164 & $(46,2)$ \\
$\quad$ Asfiksia sedang & 97 & $(27,3)$ \\
$\quad$ Asfiksia berat & 94 & $(26,5)$ \\
Umur kehamilan & & \\
$\quad$ Prematur & 147 & $(41,4)$ \\
$\quad$ Aterm & 208 & $(58,6)$ \\
Berat badan lahir (gram) & & \\
$\quad<1000$ & 5 & $(1,4)$ \\
1000-1499 & 24 & $(6,8)$ \\
1500-2499 & 136 & $(38,3)$ \\
$2500-3999$ & 184 & $(51,8)$ \\
$\quad>4000$ & 6 & $(1,7)$ \\
Awitan sepsis & & \\
SNAD & 293 & $(82,5)$ \\
SNAL & 62 & $(17,5)$ \\
Jenis bakteri penyebab & & \\
Gram positif & 152 & $(42,8)$ \\
Gram negatif & 193 & $(54,4)$ \\
Candida & 10 & $(2,8)$ \\
Kolestasis & & \\
Ya & 138 & $(38,9)$ \\
Tidak & 217 & $(61,1)$ \\
Lama rawat (hari) & & \\
$\quad<15$ & 135 & $(38)$ \\
$\geq 15$ & 220 & $(62)$ \\
\hline & & \\
& & \\
& &
\end{tabular}

neonatorum dengan kolestasis tertera pada Tabel 2. Hasil hubungan bakteri Serratia marcescens dan bakteri lain dengan terjadinya kolestasis didapatkan nilai $\mathrm{p}=0,34 ; \mathrm{RR}=0,9$ (IK 95\% 0,906-1,03),

Faktor sampel penelitian yang berhubungan dengan terjadinya kolestasis tertera pada Tabel 3 dan 4. Analisis multivariabel terhadap faktor risiko dari sampel serta faktor risiko laboratorium tertera pada Tabel 5.

Jumlah kasus kematian sepsis neonatorum 100 $(28,2 \%)$ sedangkan $32(9 \%)$ angka kematian dengan kolestasis dan 68 (19,2\%) meninggal pada pasien tanpa kolestasis dengan nilai $\mathrm{p}=0,97, \mathrm{RP}=1,23(95 \% \mathrm{CI}=$ 0,963-1,571).

\section{Pembahasan}

Sepsis merupakan spektrum klinis sebagai akibat dari kelanjutan proses inflamasi (SIRS), melalui respon imun, dengan karakteristik terdapatnya inflamasi sistemik dan faktor koagulasi. ${ }^{2}$ Kolestasis terjadi akibat gangguan sintesis dan atau sekresi asam empedu. ${ }^{14,15}$ Berbagai penelitian menyimpulkan bahwa pada keadaan infeksi dapat terjadi pelepasan sitokin yang menghambat ekspresi gen protein transporter NTCP, OATP, MRP-2, dan BSEP yang merupakan patogenesis kolestasis pada sepsis. ${ }^{16-21 .}$

Endotoksin mengganggu enzim $\mathrm{Na}^{+} / \mathrm{K}^{+}$-ATPase yang bertugas untuk menjaga intrasel menjadi lebih negatif, mengganggu tight junction pada hepatosit serta jalur transduksi sinyal antara lain kalsium dan yang dalam keadaan normal menyebabkan kontraksi kanalikulus bilier. ${ }^{16,22,23}$

Pada penelitian kami karakteristik sampel didapatkan sebagian besar bayi yang mengalami

Tabel 2. Mikroorganisme penyebab sepsis neonatorum dengan kolestasis

\begin{tabular}{lcc}
\hline Jenis kuman & Kolestasis (n) & Bukan kolestasis (n) \\
\hline Serratia marcescent & 30 & 38 \\
Acinetobacter baunanni & 10 & 24 \\
Staphylococcus coagulase negatif & 13 & 18 \\
Pseudomonas aeuginosa & 17 & 13 \\
Klebsiella pneumonia & 10 & 19 \\
Staphylococcus coagulase positif & 6 & 23 \\
Enterobacter sp & 9 & 11 \\
Flavimonas (pseudo) aryzihabitans & 9 & 10 \\
candida & 6 & 4 \\
\hline
\end{tabular}


Tabel 3. Faktor risiko sampel dengan kejadian kolestasis

\begin{tabular}{|c|c|c|c|c|c|}
\hline Karakteristik & $\begin{array}{c}\text { Kolestasis } \\
(\mathrm{n}=138)\end{array}$ & $\begin{array}{l}\text { Tidak kolestasis } \\
\qquad(\mathrm{n}=217)\end{array}$ & $\mathrm{p}$ & $\mathrm{RP}$ & IK $95 \%$ \\
\hline \multicolumn{6}{|l|}{ Jenis kelamin, $\mathrm{n}(\%)$} \\
\hline Laki-laki & $85(61,6)$ & $124(57,1)$ & 0,406 & 1,2 & $0,778-1,86$ \\
\hline Perempuan & $53(38,4)$ & $93(42,9)$ & & & \\
\hline \multicolumn{6}{|l|}{ Keadaan saat lahir, n (\%) } \\
\hline Vigorous baby & $66(47,8)$ & $98(45,2)$ & 0,91 & - & - \\
\hline Asfiksia sedang & $35(25,4)$ & $62(28,6)$ & & & \\
\hline Asfiksia berat & $37(26,8)$ & $57(26,3)$ & & & \\
\hline \multicolumn{6}{|l|}{ Umur kehamilan, n (\%) } \\
\hline Bayi kurang bulan & $62(44,9)$ & $85(39,2)$ & 0,28 & 1,26 & $0,822-1,952$ \\
\hline Bayi cukup bulan & $76(55,1)$ & $132(60,8)$ & & & \\
\hline \multicolumn{6}{|l|}{ Berat badan lahir (gram), n(\%) } \\
\hline$<1000$ & $3(2,2)$ & $2(0,9)$ & 0,633 & - & - \\
\hline $1000-1499$ & $7(5,1)$ & $17(7,8)$ & & & \\
\hline $1500-2499$ & $61(44,2)$ & $75(34,6)$ & & & \\
\hline $2500-3999$ & $65(47,1)$ & $119(54,8)$ & & & \\
\hline$>4000$ & $2(1,4)$ & $4(1,8)$ & & & \\
\hline \multicolumn{6}{|l|}{ Jenis awitan sepsis, n (\%) } \\
\hline SNAD & $109(78,9)$ & $184(84,8)$ & 0,161 & 0,67 & $0,388-1,17$ \\
\hline SNAL & $29(21,1)$ & $33(15,2)$ & & & \\
\hline \multicolumn{6}{|l|}{ Jenis bakteri penyebab, n (\%) } \\
\hline Gram positif & $48(34,8)$ & $104(47,9)$ & 0,24 & 0,599 & $0,384-0,934$ \\
\hline Gram negatif & $84(60,8)$ & $109(50,2)$ & & & \\
\hline Candida & $6(4,4)$ & $4(1,9)$ & & & \\
\hline \multicolumn{6}{|l|}{ Lama rawat (hari) } \\
\hline$<15$ & $10(7,2$ & $125(57,6)$ & 0,001 & 0,058 & $0,029-0,116$ \\
\hline$\geq 15$ & $128(92,8)$ & $92(42,2)$ & & & \\
\hline Lama puasa rerata $(\mathrm{SB})^{*}$ & $8,87(6,81)$ & $3,44(2,40)$ & 0,001 & $5,43^{* *}$ & $4,436-6,425$ \\
\hline Lama nutrisi parenteral, rerata $(\mathrm{SB})^{*}$ & $14,12(8,26)$ & $6,3(3,17)$ & 0,001 & $7,82^{* *}$ & $6,594-9,046$ \\
\hline
\end{tabular}

*SB: simpangan baku; RP: rasio prevalen; ${ }^{* *}$ mean difference

Tabel 4. Faktor risiko nilai laboratorium indikator sepsis neonatorum dengan kejadian kolestasis

\begin{tabular}{lccccc}
\hline Faktor Risiko & $\begin{array}{c}\text { Kolestasis } \\
\mathrm{n}=138\end{array}$ & $\begin{array}{c}\text { Tidak kolestasis } \\
\mathrm{n}=217\end{array}$ & $\mathrm{p}$ & $\begin{array}{c}\text { Mean } \\
\text { difference }\end{array}$ & IK 95\% \\
\hline Leukosit, rerata (SD) & $20,400(22192,6)$ & $17,600(7877,9)$ & 0,094 & 2768,2 & $472,9-6009,5$ \\
CRP, rerata (SD) & $97,51(74,94)$ & $23,27(36,58)$ & 0,001 & 74,24 & $62,51-85,97$ \\
IT ratio, rerata (SD) & $0,07(0,05)$ & $0,03(0,03)$ & 0,001 & 0,03 & $0,026-0,045$ \\
Trombosit, rerata (SD) & $60,250(60,950)$ & $158,830(79,460)$ & 0,001 & $-98,570$ & $-114,172-(-82,975)$ \\
\hline
\end{tabular}

Tabel 5. Analisis multivariabel

\begin{tabular}{lccc}
\hline Faktor risiko & $\mathrm{RP}$ & $\mathrm{p}$ & $\mathrm{IK} 95 \%$ \\
\hline Lama rawat & 0,184 & 0,008 & $0,712-0,950$ \\
Lama puasa & 0,892 & 0,001 & $0,725-0,913$ \\
Lama nutrisi parenteral & 0,810 & 0,001 & $0,056-0,302$ \\
CRP & 0,981 & 0,001 & $0,000-0,999$ \\
IT ratio & 0,041 & 0,001 & $1,011-1,023$ \\
Trombosit & 1,017 & 0,001 & $1,011-1,023$ \\
\hline
\end{tabular}


sepsis $184(51,8 \%)$ neonatus memiliki berat badan lahir normal 2500-3999 gram. Hasil tersebut tidak sesuai dengan faktor risiko untuk terjadinya sepsis yaitu neonatus dengan berat badan lahir kurang. Penelitian Shamir $\mathrm{dkk}^{24}$ menunjukkan berat badan lahir $<2500$ garm sebagai populasi tertinggi yang mengalami sepsis dengan Gram negatif. Perbedaan disebabkan kemungkinan karena 208 (58,6\%) kasus didapatkan umur kehamilan atau usia gestasi ibu berkisar 37-42 minggu.

Pada penelitian kami angka kejadian atau prevalensi kolestasis pada sepsis neonatorum 38,9\%. Sedikit berbeda dengan penelitian Oswari $\mathrm{dkk}^{25}$ yang menemukan secara retrospektif angka kejadian kolestasis pada sepsis neonatorum dari 47 bayi di NICU dan di ruang rawat neonatologi $74,5 \%$ berdasarkan proven sepsis. Penelitian Bachtiar ${ }^{8}$ menunjukkan angka kejadian kolestasis pada sepsis 65,9\% dengan jumlah sampel 138 sampel dengan proven atau clinical sepsis.

Spektrum mikroorganisme penyebab sepsis neonatorum pada setiap rumah sakit berbeda. Penyebab sepsis neonatorum pada penelitian kami sebagian besar merupakan bakteri Gram negatif $(54,4 \%)$, dengan mikroorganisme tersering adalah Serratia marcescens (19,2\%), diikuti oleh Acinetobacter baumanni (9,6\%) dan Staphylococcus coagulase negatif $(8,7 \%)$. Hal tersebut sesuai dengan berbagai kepustakaan yang menyebutkan bahwa sebagian besar penyebab sepsis neonatorum berasal dari bakteri Gram negatif. ${ }^{26}$

Dari 138 kasus kolestasis yang terjadi pada sepsis neonatorum, kadar bilirubin direk meningkat $59,8 \%$ dari bilirubin total. Bachtiar ${ }^{8}$ mendapatkan peningkatan kadar bilirubin direk terhadap bilirubin total yang hampir sama yaitu sekitar $55,3 \%$. Sedangkan Tiker $\mathrm{dkk}^{27}$ mendapatkan kadar bilirubin direk yang meningkat $44,1 \%$ dari bilirubn total, (rerata bilirubin direk $12,9 \mathrm{mg} / \mathrm{dL}$, dari rerata bilirubin total 29,2 $\mathrm{mg} / \mathrm{dL}$ ). Tingkat kenaikan bilirubin direk yang lebih tinggi kemungkinan karena sepsis yang terinfeksi jenis bakteri Gram negatif yang berbeda atau karena lama puasa yang berbeda sehingga memerlukan penelitian lebih lanjut. Dari kepustakaan dikatakan sepsis yang terinfeksi bakteri Gram negatif akan lebih meningkat pada puasa lama yaitu 7,3 $\pm 6,3$ hari, apabila dibandingkan dengan bayi yang terinfeksi Gram negatif dengan puasa yang lebih singkat selama 4,0 $\pm 4,3$ hari. ${ }^{24}$ Kami mendapatkan rerata puasa pada pasien kolestasis $8,8 \pm 6.8$ hari.
Terdapat perbedaan bermakna antara rerata lama rawat kasus sepsis neonatorum dengan kolestasis (29,7 hari) dan tidak kolestasis (12,5 hari). Hasil tersebut serupa dengan penelitian Bachtiar, ${ }^{8}$ yang menunjukkan rerata lama rawat kasus kolestasis-sepsis 27,8 hari sedangkan tidak kolestasis 17,6 hari. Temuan kolestasis dalam penelitian kami ternyata dapat mempengaruhi lama rawat pasien di rumah sakit.

Hubungan faktor risiko berdasarkan hasil laboratorium indikator sepsis pada saat terdiagnosis kolestasis yaitu kadar CRP, trombosit, dan IT ratio bermakna terjadinya kolestasis sedangkan untuk kadar leukosit tidak bermakna dalam menentukan terjadinya kolestasis. Hasil tersebut sedikit berbeda dengan penelitian Bachtiar $^{8}$ yang menemukan tidak terdapat hubungan bermakna antara kadar leukosit, CRP, dan IT ratio. Kemungkinan disebabkan oleh pemeriksaan tersebut dilakukan pada saat awal terdiagnosis sepsis neonatorum sedangkan pada penelitian kami pengambilan data laboratorium saat terdiagnosis kolestasis sehingga memberikan hasil yang berbeda.

Sebagian besar kasus yaitu 128 kasus (92\%) dengan kolestasis pada sepsis neonatorum menjalani perawatan selama lebih atau sama dengan 15 hari terdapat hubungan bermakna untuk terjadinya kolestasis. Didukung penelitian Bachtiar ${ }^{8}$ yang menunjukkan $56,6 \%$ kolestasis sepsis menjalani perawatan $\geq 15$ hari. Hal tersebut belum dapat dijelaskan sehingga diperlukan penelitian lebih lanjut, apakah lama rawat berpengaruh dengan lama puasa dan lama pemberian nutrisi parenteral.

Pemberian nutrisi parenteral dapat menimbulkan masalah yaitu menimbulkan kerusakan pada hepar serta membawa bakteri masuk ke aliran darah. Pada PNAC, pemberian glukosa yang berlebihan akan menyebabkan peningkatan sintesis asam lemak di hepar dalam bentuk lipoprotein yang berakibat timbulnya inflamasi dan fibrosis serta sirosis. Pemberian asam amino dapat menyebabkan peningkatan garam empedu di empedu sehingga dapat menimbulkan kolestasis. ${ }^{28}$

Jumlah kematian sepsis neonatorum pada penelitian kami $100(28,2 \%)$ kasus sedangkan kematian sepsis neonatorum dengan kolestasis 32 (9\%) kasus, dan terdapat 68 (19,2\%) kasus meninggal pada pasien tanpa kolestasis. Hasil tersebut berbeda pada penelitian Bachtiar ${ }^{8}$ yang menunjukkan risiko relatif neonatus yang meninggal akibat kolestasis 
adalah 2,25 (1,30-3,92) yang dapat menjadi faktor prognostik. Namun hasil berbeda ini belum terdapat penelitian-penelitian yang membahasnya secara spesisfik.

\section{Kesimpulan}

Angka kejadian (prevalensi) kolestasis pada sepsis neonatorum di RSUP Sanglah Denpasar didapatkan $38,9 \%$ dengan penyebab terbanyak bakteri Gram negatif yaitu Serratia marcescens (19,2\%). Lama rawat $\geq 15$ hari, lama puasa, serta pemberian nutrisi parenteral, kadar CRP, IT ratio, dan trombosit bermakna untuk terjadi kolestasis. Angka kematian sepsis neonatorum dengan kolestasis sebesar $9 \%$ tidak berbeda bermakna dengan tanpa kolestasis.

\section{Daftar pustaka}

1. Gomella TL, Cunningham MD, Eyal FG. Neonatology: management, procedures, On-call problems, disease and drugs. Edisi keenam. USA: Mc.Graw Hill; 2009.

2. Oswari H. Kolestasis: Atresia bilier dan sindrom hepatitis neonatal. PKB IKA LIII; Jakarta, Indonesia; 12-13 November 2007.

3. Girard M, Lacaille F. Diagnosis of neonatal cholestasis. Ann Nestlé [Engl] 2008; 66:109-20.

4. Kamath BM. Neonatal cholestasis: excerpt from the 5-minute pediatric consult. Didapat dari http://www. wrongdiagnosis.com.

5. NASPGHAN. Guideline for the evaluation of cholestatic jaundice in infants: recommendations of the North American Society for pediatric gastroenterology, hepatology and nutrition. J Pediatr Gastroenterol Nutr. 2004; 39:115-28.

6. Kadim M, Salakede SB, Hartantyo I, Athiyah AF, Rosalina I. Modul B: kolestasis pada bayi. Dalam: Juffrie M, Mulyani NS, penyunting. Modul pelatihan kolestasis. Edisi pertama. Jakarta: UKK Gastro-Hepatologi IDAI; 2009.

7. Oswari H, Harijadi, Bisanto J, Purnamawati SP. Infeksi saluran kemih sebagai penyebab kolestasis intrahepatik. Sari Pediatri 2005; 6:166-71.

8. Bachtiar KS. Angka kejadian kolestasis intrahepatik pada sepsis neonatorum dan faktor risiko kolestasis sepsis (tesis). Jakarta: Departemen Ilmu Kesehatan Anak Fakultas Kedokteran Universitas Indonesia; 2007.
9. Trauner M, Fickert P, Stauber RE. Inflammationinduced cholestasis (abstract). J Gastroenterol Hepatol. 1999; 14:946-59.

10. Tanasescu C. Correlation between cholestasis and infection. Rom J Gastroenterol 2004; 13:23-7.

11. Wright K, Ernst KD, Gaylord MS, Dawson JP, Burnette TM. Increased incidence of parenteral nutritionassociated cholestasi with aminosyn pf compared to trophamine. J Perinatol 2003;23:444-50.

12. Rodrigo I. Changing patterns of neonatal sepsis. Sri Langka J Child Health 2002;31:3-8.

13. Gerdes JS. Diagnosis and management of bacterial infections in the neonatal. Pediatr Clin N Am 2004; 51:939-59.

14. Trauner M, Meier PJ, Boyer JL. Molecular pathogenesis of choletasis. N Engl J Med 1998;339:1217-27.

15. Boyer JL. Bile secretion models, mechanisms and malfunctions: a perspective on the development of modern cellular and molecular concepts of bile secretion and cholestasis. J Gastroenterol 1996;31:475-81.

16. Gilroy RK. Mailliard ME. Gollan JL. Cholestasis of sepsis. Best Pract Res Clin Gastroenterol 2003;17:357-67.

17. Trauner M, Fickert P, Stauber RE. Inflammation-induced cholestasis (abstract). J Gastroenterol Hepatol 1999; 14:945-59.

18. Whiting JF, Green RM, Rosenbluth AB, Gollan JL. Tumor necrosis factor-alpha decrease hepatocyte bile salt uptake and mediates endotoxin-induced cholestasis. J Hepatol 1995; 22:1273-8.

19. Vos TA, Hooiveld GJEJ, Koning H, Childs S, Meijer DKF, Moshage $\mathrm{H}$, dkk. Up regulation of the multidrugs resistance genes, Mrp1 and Mdr 1b and down regulation of the organic anion transporter, Mrp 2 and the bile salt transporter, spgp in endotoxemic rat liver. J Hepatol 1998; 28:1637-44.

20. Geier A, Dietrich CG, Voight S, Kim SK, Gerloff T, Kullak-Ublick GA, dkk. Effect of proinflammatory cytokines on rat organic anion transporters during toxic liver injury and cholestasis. J Hepatol 2003; 38:345-54.

21. Tanases C. Correlation between cholestasis and infection. Rom J Gastroenterol 2004;13:23-7.

22. Szabo G, Romics L, Frendi G. Liver in sepsis and systemic inflammatory response syndrome. Clin Liver Dis 2002;6:1045-66.

23. Geier A, Fickert P, Trauner M. Mechanisms of disease: mechanisms and clinical implications of cholestasis in sepsis. Nat Clin Pract Gastroenterol Hepatol 2006; 3:574-85. 
24. Shamir R, Metzger AM, Bujanover Y, Ashkenasi S, Dinari G, Sirota L. Liver enzyme abnormalities in gram negatif bacterimia of premature infants. Pediatr Infect Dis J 2000;19:495-8.

25. Oswari H, Siagian M, Bisanto J. Neonatal liver disease in Cipto Mangunkusumo Hospital. Abstract KONIKA XIII; Bandung, Indonesia 4-7 Juli 2005

26. Junianingsih A, Aminullah A, Firmansyah A. profil mikroorganisme penyebab sepsis neonatorum di Departemen Ilmu Kesehatan Anak Rumah Sakit Cipto Mangunkusumo Jakarta. Sari Pediatri 2008;10:60-5.
27. Tiker F, Tarcan A, Killicdag H, Gurakan B. Early onset conjugated hyperbilirubinemia in newborn infants. Indian J Pediatr 2006;73:409-12.

28. Jeejeebhoy KN. Management of PN-induced cholestasis. Pract Gastroenterol 2005;24:61-5.

29. Blau J, Shidhar S, Mathieson S, Chawla A. Effects of protein/nonprotein caloric intake on parenteral nutrition associated cholestasis in premature infants weighing 600-1000 grams. JPEN J Parenter Enteral Nutr 2007; $31: 487-90$. 